\title{
Transformative Presidents: A Review of Definitions, Focused on the Reagan Presidency
}

\author{
William A. P. Thompson Jr. \\ University of Texas at Dallas, Dallas, USA
}

\begin{abstract}
The most significant variable in ranking a President as transformative is the nature of his legacy. Reagan's legacy resulted from the Tea Party's adoption of Reagan's conservative policy proposals, labeled the Reagan Revolution, or as Reagan defined in his farewell address, the “... Great Rediscovery, a recovery of our values and common sense" (Skowronek, 1967, p. 95). Transformative presidents create changes in the American Political System. Stephen Skowronek has defined five transformational presidents whose administration transformed the American political system: Jefferson, Jackson, Lincoln, Franklin D. Roosevelt, and Reagan (Skowronek, 1967, p. 95). Further, a comparison of the Reagan and Obama presidencies is included to explain why a President may be defined as being or not transformative. Each of these transformation repudiated their predecessor's policies. The Reagan Revolution enabled Reagan to become transformative by repudiating Carter's New Deal liberal and progressive policies. Presidential scholars who deny the ability of presidents to become transformative do so based on their research that presidents lack the power to persuade Congress or change public opinion. Skowronek utilized Neustadt's theory of "periodization" to explain how the five transformational presidents each left through their “legacy”, presidents who followed their policies. Reagan's followers included: George Bush, Clinton's centrist policies adhered to Reagan's, and George W. Bush. Obama was elected by repudiating his predecessor's policies. Whether Obama was transformative has yet to be determined.
\end{abstract}

Keywords: transformative, Reagan presidency, periodization

\section{Transformative Presidents Have a Legacy}

Richard E. Neustadt's, Presidential Power and the Modern Presidents explained a reason for considering why some presidents are transformative: "we like to 'rate' a President" (Skowronek, 1967, p. 3).

He interchanged "rating" with "Appraising" a president in a chapter on the subject. He explained that we are evaluating presidents by making "judgments about presidential leadership" (Skowronek, 1967). Neustadt listed four questions for determining performance. For this paper, I am selecting his fourth question, in analyzing Present Ronald Reagan's transformative Presidency: "what was his legacy?" Neustadt's other questions: (1) what was the purpose, e.g., health care reform; (2) what is his "feel" or operating style; and (3) what was the "man's response" to pressure (Skowronek, 1997, p. 168)?

Neustadt's comment that "we like to 'rate' a President" suggests an excellent introduction about how to both define and introduce the meaning of transformative presidents. Neustadt does not define the term "transformative". Several political scientists have offered ways to understand the concept without really giving

William A. P. Thompson Jr., Adjunct Professor, Department of Political Science, University of Texas at Dallas. 
a succinct definition. George C. Edwards III, has written about the vagueness of explaining the meaning:

It would be easy to become enmeshed in debates about whether a particular president was "transformational". The issue is not whether policy changes that president's desire occur. They do. Neither is the issue determining when change is large enough that we may consider it to be transformational... I am interested in significant changes, whether or not they are "transformational"'. (Edwards, 2009, p. 9)

Edwards cannot define a transformative President because a president lacks the power to persuade:

The fundamental question is whether presidents have the potential to persuade others to follow them?... Can presidents transform politics through persuasion?... There is not a single systematic study that demonstrates that presidents can reliably move others to support them. (Edwards, 2013, p. 9)

\section{Transformative Presidents Exert "Leadership" in Their Reconstructions}

In essence, Edwards can neither define what a transformational, and rejects the idea that Presidents can be transformative because they lack the power to persuade Congress or public opinion to enact policy. To solve the definitional problem, Edwards proposed creating a special issue of Presidential Studies Quarterly to feature historical research on the Presidency. In the article, the authors wrote, for example, that "One of the central themes of the historical turn in presidential studies is the role of presidents in the periodic transformation of American government" (Miroff \& Skowronek, 2014). In this article, the author, mention the presidents who have made major transformations, including Franklin Delano Roosevelt (FDR) and Reagan (Miroff \& Skowronek, 2014). Also, pertaining to this paper, why not utilize historical research, as well, in "rating" Presidents?

Both Edwards and Skowronek refer to James MacGregor Burns' Leadership, which defines leadership, and explains why it is necessary for explaining the meaning of a transformative leader. Burns studied several presidents, including FDR and John Kennedy in explaining through exhaustive historical biographies of how Presidents can be transformative. Burns (1978) explained transformative leadership as “... when one or more persons engage with others in such a way that leaders and followers raise one another to higher levels of motivation and morality" (p. 30). In his definition of leadership, Burns (1978) used the example of Gandhi, “... who aroused and elevated the level of human conduct and ethical aspiration of both leader and led, and thus has a transforming effect on both" (p. 30).

\section{Periodization}

Stephen Skowronek, Presidential Leadership in Political Time, also questioned whether transformational presidents exist, but, agreed that the changes that occur during their tenure may be large enough to be transformational. Skowronek (1997) applied Neustadt's model in Presidential Power to explain the definition of transformational presidents by demonstrating how presidents introduce a “... periodization of presidential history... introduced a sense of cohesion into the relentless succession of Incumbents..." (p. 5). In addition, he explained why there were only five Presidents, Jefferson, Jackson, Lincoln, FDR and Reagan whose leadership could be judged transformational.

Skowronek also added another way of analyzing transformative presidents through introducing the idea of a "new kind of presidency", pursued by Theodore Lowi (1985), The Personal President, to explain the periodic changes in the presidency. Lowi (1985) described the changes in the development of the modern presidency “... so sweeping as to amount to the founding of a 'second republic". The transformation that Lowi described 
referred to Reagan's "Plebiscitary" presidency. Reagan's reconstruction amounted to a "personal presidency" which through the campaign where the personality of the president is revealed. "The plebiscitary presidency is a personal presidency and that fact can already be seen in the campaign" (Lowi, 1985, p. 115). During his campaigns, Reagan employed polling to validate and evaluate his standing with the "masses" (Lowi, 1985, p. 116).

Skowronek listed transformative changes in the presidency that amounted to creating periodization during the succession of, for example, early, modern, or progressive presidents:

They divide presidential history into a modern period and a traditional period; they set the modern presidents together analytically as creatures of a different sort; they pull the modern presidents together analytically as a coherent group for comparison. Analysts are directed in this way to evaluate Progressives aspirations and achievements, and the early American presidents are rendered largely irrelevant to an understanding of how the office works today. (Skowronek, 2011, p. 15)

Skowronek realized that Lowi described periodization, as only between modern and traditional presidencies, by coupling presidents so as to identify transformative presidents who have opposed their predecessor's existing policies. Skowronek's The Politics Presidents Make grouped together four "periods" of presidential leadership with chapter titles: Jeffersonian Leadership-Patrician Prototypes; Jacksonian Leadership - Classic Forms; Republican Leadership (beginning with Abraham Lincoln) and Liberal Leadership: Fraying Boundaries (beginning with Franklin Roosevelt's Reconstruction and ending with Jimmy Carter's Disjunction). His fifth period, "Reagan, Bush, and Beyond" constituted a chapter such as the four previous ones, and was included in a chapter following "Roosevelt's Reconstruction".

Skowronek, explained a transformative president as one who followed a course of action using Neustadt's "four requirements" that identified five Presidents who have made significant changes in their predecessor's policies. Each of these presidents was divided into one of five chapters in The Politics Presidents Make.

\section{Reagan or Obama: Is Transformational Leadership Still Possible?}

Skowronek (2011) discussed transformative leadership in "Is Transformational Leadership Still Possible? Barack Obama in Historical Perspective". Skowronek questioned whether transformational leadership is possible, reviewed the paths of the five transformative presidents through an appraisal of Obama's presidency. President Obama, prior to campaigning, had written The Audacity of Hope outlined the steps he planned to improve America. All transformative presidents initiated their leadership through repudiating predecessors (Obama, 2006).

Obama initiated his general election campaign against John McCain by identifying and emulating two other transformative presidents, Lincoln and Reagan to show how he wished to follow their examples. Obama campaigned about change by belittling President Clinton's "temporizing" rather than repudiating existing policies (Skowronek, 2011, p. 169). It was not clear that Obama clearly established a "unifying vision" in attacking President George Bush's "profound irresponsibility". Obama was elected asserting that he wanted to unify partisan factions through mutual agreement. After being elected, Obama failed to include any of the opposition factions into his coalition. Not doing so, determined that Obama was not transformative. Skowronek asked whether transformative leadership was possible, then, questioned if Obama's, reelection and passing his signature health care reform resulted in his being transformative? Several other political scientists also asked whether Obama, or any other President, was transformative. Their analysis of his presidency provides insight 
into defining transformation. George C. Edwards III, too, doubted whether Obama, or any other President, was transformative. Edwards' title: Overreach, appraised Obama's presidency as having overreached his ability to persuade Congress or public to accept his policies.

In Overreach, Edwards questioned: (1) was there opportunity for public and congressional support in promoting Obama's major policies, including the Affordable Care Act, TARP or the Stimulus, and (2) "what were these opportunities", and what was the likely success of creating opportunities by "going public"? (Edwards, 2012, p. 7), to both questions, Edwards believed that Obama pursued activist legislation without tangible opportunities for success.

In "Narrowcasting the Obama Presidency", Andrew Rudalevige (2013) also agreed that Obama was not transformative agreeing with Neustadt that Political Science has an important role in rating presidents, and reviewed a number of studies to explain when a president could be categorized as a "transformative".

\section{Why was Obama Not Transformative?}

Theda Skocpol (2012) assessed Obama's presidency which she paralleled with FDR's, compared to FDR's transformative presidency, Obama's was "Far from the advent of sustained Democratic dominance... the early Obama presidency gave way to a conservative backlash... and, at best, a 'halfway New Deal'" (pp. 93-94).

Transformative presidents must demonstrate their commitment to sustaining and changing their predecessor's policies, that was consistent with their initial purpose.

Instead, Obama's policies were consistently challenged both in Congress and with the public as evidenced by lack of poll support and defeat in the 2010 and 2014 mid-term elections. "... Reconstructive leaders... have discovered the true basis of national unity and are acting to restore it" (Skowronek, 2011, p. 175).

In addition to restoring national unity, reconstructive leaders change the old order with a new vision. Skowronek explained why Obama was not transformative since he had not reconstructed his party, by bringing new groups to form political alliances favorable to his progressive policies. Obama failed to accomplish what Reagan had in repudiating FDR's of New Deal policies.

\section{Reagan: A Format for Determining Whether a President is Transformative}

Skowronek, followed Neustadt, in rating various Presidents to determine their level of presidential leadership, and suggested a format for defining a transformative, for example, by determining whether a particular president repudiated his predecessor's vision for creating new policies. Skowronek believed five transformative presidents benefited from problems associated with their predecessor's policies. For example, Reagan was elected to end high inflation, high interest rates and unemployment. Reagan campaigned that the economy suffered from the welfare policies enacted by FDR's New Deal. Reagan's reconstructive vision attributed New Deal, government, progressive, legislation as incorrect in solving problems.

Reagan's, instead, referred to the libertarian beliefs of the founders who opposed the expansion of government infringing on individual liberty. Reagan also attacked progressive, judicial interpretations of the Constitution that perceived the Constitution as a living document to be adapted to solutions to social or economic problems. Reagan's judicial conservatives interpreted the Constitution fundamentally, rather than according to the situation.

Reagan's rhetoric, praising America as the "Shining City on the Hill", provided balm for Americans who were increasingly pessimistic about the outcome and duration of the Vietnam War. Reagan's leadership 
proclaimed that Government was not the solution. Reagan suggested a solution through hyperbole, by illustrating his attacks on welfare by saying only "welfare queens" benefited. Reagan's transformative presidency targeted high taxes that Reagan proposed to reduce together with budget deficits, caused by welfare policies enacted during FDR's New Deal.

The most important part of the Reagan Revolution that reconstructed the Republican Party consolidated a coalition "... to support the new agenda and dominate electoral politics" (Skowronek, 2011, p. 97). Reagan enacted the 1981, Kemp-Roth Economic Recovery Act, fulfilling his campaign promises of reducing taxes, encouraging savings, to increase supply. This act reversed FDR'S New Deal Keynesian macroeconomics which expanded government funding to increase demand and encourage employment.

\section{Reagan's Legacy}

In The Triumph of Politics, David Stockman (1986) advocated Supply Side economics to promote economic growth ending high inflation and Carter's stagnant economy. Stockman wrote that "... the supply-side synthesis offered two powerful, classic economic truths". The first truth was "... our capitalist economy's natural capacity to expand and generate new wealth and societal welfare was hobbled by sweeping anti-supply and incentive-destroying policies of the modern state" (Stockman, 1986, p. 41). His second truth asserted that the dollar's value was declining, due to failed monetary policy that created global inflation (Stockman, 1986, p. 41). Both of Stockman's "truths" supported the Economic Recovery Act which served as the basis of the Reagan Revolution to end New Deal policies. The Kemp Act reduced personal income taxes by $25 \%$ over a three-year period.

In addition, marginal tax rates were reduced from a range of $14 \%$ to $70 \%$, resulting in only a minor reduction at the bottom end of the income brackets, but a very significant reduction at the highest income brackets (Dye, 1998, p. 176).

David A. Stockman, analyzed the impact of the Economic Recovery Act to show why the Reagan Revolution failed. Stockman explained why Supply Side economics, by reducing income tax rates created a massive federal deficit.

David Stockman, appointed Director of the Office of Manager of the Budget, pushed the Kemp tax cuts through Congress. Also, he followed Reagan's campaign promise to enact massive defense spending. However, Congress denied reducing Social Security and Medicare benefits that were needed to balance the budget. (Stockman, 1986, p. 125). According to Stockman, the Reagan Revolution ended as a result of failing to balance the budget by reducing entitlements. What is the Reagan legacy? Stockman believed that it was the national debt that resulted from a lack of revenue as a result of the "Kemp-Roth" income tax reduction:

Regan's most prominent legacy, the national debt, weighed against the economic miracle he had promised from the private sector as much as against the public-sector initiatives he had renounced, and the two reconstructive ideas on which he had rested his new course -the monetarist discipline-the monetarist discipline and the supply-side stimulus to invest-a appeared all the more dubious after the recovery took hold. (Skowronek, 1997, p. 428)

But, Reagan's legacy also included reducing taxes and creating a conservative agenda for limited government. A president is transformative when his policies are followed by future Presidents, i.e., President George W. Bush, who continued upgrading the military and advocating privatization. Bush also transacted a tax cut larger than Reagan's, adhering to Kemp-Roth supply-side economic policy. President Bush continued Reagan's educational reform by enacting a signature education reform that strengthened public schools with 
standardized, rigorous national testing of core curriculum.

In 2008, Obama was elected at the beginning of the Great Recession. He enacted progressive policies that contrasted with both Bush's and Reagan's conservative vision. Obama opted to promote progressive federal funding to stimulate the economy. Obama's Presidency was reconstructive, opposing Reagan's belief that Government is the problem. Obama's governmental policies to end the Great Recession caused a conservative reaction that galvanized Republican leaders to oppose Obama's policies (Thompson, 2012).

February, 2009, shortly after Obama was inaugurated, the Illinois libertarian party inspired CNBC Rick Santelli to request revolutionary, Tea Party resistance to protest mortgage assistance. Reporting from the floor of the Chicago Mercantile Exchange, Santelli called for a "Tea Party" to protest policies such as the "Stimulus" and TARP that were enacted to end the Great Recession:

This is America... How many of you people want to pay for your neighbor's mortgage that has an extra bathroom and can't pay their bills?... if you read our Founding Fathers, people like Benjamin Franklin and Jefferson, what we're doing in this country now is making them roll over in their graves. (Skocpol \& Williamson, 2012, p. 45)

\section{Tea Partiers Embrace Reagan's Legacy}

Santelli's comment restated Reagan's legacy. The Tea Party revived a movement to continue all that President Reagan championed during his transformative presidency. Most significantly, the Tea Party followed Reagan in opposing any form of welfare policy, including providing subsidization for "losers' mortgages and reward people who "can carry the water instead of drink the water". Tea Partiers demanded everything that Reagan achieved in opposing welfare policies.

Alan Abramowitz (2011) described the Tea Party as “... part of the long-term growth of partisan ideological polarization with the American electorate and especially the growing conservatism of the Republican Party" (p. 3).

Demographically, the Tea Party consists disproportionally of mostly older white males, affluent, evangelical Christians, gun owners who are less likely than non-supporters to be college graduates.

Leigh Bradberry and Gary C. Jacobson (2013) also described Tea Partiers,

... intense hostility to Barack Obama... beyond hostility to his legislative agenda-most prominently... the Affordable

Care Act (ACA)-Tea Partiers questioned Obama's character, ... His name, race, origins, associations, political background, and cerebral style had Rattled peopled sharing right-wing populist sentiments even before he was elected... (p. 2)

Tea Partiers expressed racist and anti-immigrant beliefs, of older, white Americans. But according to Edmund Morris (1999), there was no evidence for Reagan having racist or nativist prejudice. Theda Skocpol and Vanessa Williamson through interviews with Tea Partiers have added more depth to understanding Tea Partiers' ideology as a way to link with Reagan's legacy. Tea Partiers embraced limited government and "Freedom to Pursue Prosperity through unhindered Markets... and Liberty tempered Virtue... and hold true to the visions of our founding fathers" (Skocpol \& Williamson, 2012, p. 48).

Tea Partiers' conformity adhered to social conservatism regarding race, age, or pro-life, but many are “... secular minded libertarians... who stress individual choice on cultural matters and want the Tea Party... to give absolute priority to fiscal issues" (Skocpol \& Williamson, 2012, p. 35).

A direct tie of Tea Party conservatives to Reagan's legacy is associated with Senator Rand Paul's landslide victory over a traditional Republican in the Mid-Term elections. In addition to Tea Partiers' opposition to 
Obama and Democratic Party candidates, Tea Partiers opposed Republican elites not adhering with Tea Partier ideology. Rand Paul's mid-term Senate victory was achieved through his success in the Kentucky primaries against an "establishment" Republican. Tea Partiers remain consistently Republican, but have refuted Republicans, such as Senator Bob Bennett who voted for the "Bank Bailout" (Skocpol \& Williamson, 2012, p. 42). Tea Party Republicans differ with establishment Republican who compromise with Democrats.

Rand Paul's association with Reagan's political beliefs was described In the Tea Party Goes to Washington, Rand Paul remembered how he and his father, Ron Paul, helped Reagan's 1976 Presidential candidacy against Vice President Nelson Rockefeller. Ron Paul balanced his libertarian beliefs “... against the need to protect his country and interests" (Paul \& Hunter, 2011, p. 3).

During the 2010 election, Rand Paul explained why he and other Tea Partiers concerned about the national debt, yet supported massive defense spending.

Rand Paul's Tea Partiers, influenced both Republican conservative politics and libertarian ideology. Paul's ideology always correlated with Tea Partier libertarianism, together with Reagan's antipathy for big government. Republican elites in both the Senate coalesced to form a conservative coalition opposed to all perceived socialist or progressive legislation, including

Obama's signature health reform care act, "Obama Care". In the face of Republican Party opposition, strengthened by the Tea Party, President Obama pursued his signature, Affordable Health Care policy. No Republican member of the House or Senate voted for AFC. Still, the 111th Democratic controlled Congress enacted AFC through reconciliation.

The 2010 election resulted in a 63-seat-loss of Democratic Representatives. David W. Brady and his colleague examined reasons for Democratic losses other than Tea Party conservative opposition.

The conservative House, galvanized by the Tea Party countered AFC and any other policies proposed by President Obama. Is this opposition a continuing support for Reagan's legacy? Yes, Tea Partier conservatism has followed Reagan's ideology. In addition, Leigh Bradbury and Gary Jacobson (2013) provided stronger evidence that Tea Partiers also affected the 2012 Presidential election wrote that “... goals and sentiments that motivated Tea Partiers... were the driving force between the broad Republican victory helped all Republicans regardless of their degree of association with the movement" (p. 32).

\section{Conclusions}

The purpose of this paper reviewed political scientists' definitions of rating a president's leadership which supports the possibility of having a definition of a transformative president. one of which is the subject for this paper. Neustadt proposed four ways of rating a president, one of which is central to this paper for appraising a President. Does a President leave a legacy or “... clues in the conduct of the next Administration" (Neustadt, 1990, p. 168).

... what was his legacy? What imprint did he leave on the office, its character, and public standing; where did he leave his party and the other party nationally; what remained by way of public policies adopted or in controversy; what remained as issues in American society, insofar as own stance may have affected them...”. (Neustadt, 1990, p. 167)

Neustadt appraised Presidents FDR, Truman, Eisenhower, Kennedy and LBJ, none of whom could be confirmed as transformative. In the revised edition of Presidential Power, he expanded his appraisal in detail to include President Reagan as compared with FDR. 
Neustadt's appraised Reagan negatively as a result of the "Iran Contra" affair, which Neustadt believed should have resulted in Reagan's impeachment. Neustadt favorably balanced Reagan's "Iran Contra" affair with his high approval ratings that equaled FDR's. High approval of a President's policies demonstrated “... the country's consciousness of what its government should be and do" (Neustadt, 1990, p. 271) When a President has persuaded public opinion to be in agreement with his administration determined the leadership rating.

I explain that Reagan's legacy was the effect his policies and philosophy, expressed in his 1981 inaugural address became the Reagan Revolution: "In the present crisis, government is not the solution to our problem; government is the problem" (Skowronek,1997).

I have suggested the similarities between Reagan's conservative ideologies and those of Tea Party candidates in the 2010 and 2012 elections that confirmed Reagan as a "Transformative President" (Bond, Fleisher, \& Ilderton, 2011; Fisher, 2014; Formisano, 2012). I have described the leading presidential scholars on the topic (Thompson, 2014). Edwards agreed with Neustadt's classic work on Presidential Power by reviewing presidents whose leadership changed American politics have taken on "mythic proportions as leaders" (Edwards, 2013, p. 1). Edwards debunked each so-called transformative as failing to persuade Congress or affect public opinion. Again, not all presidential scholars agree that Presidents may be defined as transformational. Skowronek, The Poltics Presidents Make, researched and analyzed the presidents through Clinton to create a framework for studying the possibility of having a transformative president. Skowronek's Presidential Leadership, revised his previous conclusions In the Politics Presidents Make, by comparing Obama's with Reagan's, satisfy the necessary criteria for determining who is transformative. The result of the comparison demonstrated that President Obama has not yet been proven to be transformative.

Larry M. Bartels (2012) appraised Obama's presidency and wondered about both the meaning of the concept, transformative, and, if one ever existed. In assessing Obama's Presidency, compared with FDR's, Bartels (2012) queried if FDR would have been elected for a second term if the “... recession of 1938 had happened two years earlier" (p. 108). Bartels wrote that a president's transformative status or even reelection was based on economic distress or income growth. He (2012) added, "If even the New Deal era does not live up to our heroic expectations for 'transformational' politics, what chance has Obama?" (p. 109). But, "periodization" theory does demonstrate that five transformative Presidents, including Reagan have had legacies.

I conclude that none of the presidential scholars, included in this paper, have succinctly defined a transformational President. Possibly Miroff and Skowronek (2014), are correct, that future historical research will provide insights into the meaning of a transformative president. Historians used to rank or appraise all of the Presidents by listing, for example, the 10 worst and 10 best.

\section{References}

Abramowitz, A. I. (2011). Partisan polarization and the rise of the Tea party Movement. 2011 Annual Meeting of the American Political Science Association, Seattle.

Bartels, L. M. (2012). A new deal fantasy: Misreading the mandate. In T. Skocpol (Ed.), Obama and America's future (pp. 93-110). Cambridge: Harvard University Press.

Bond, J. R, Fleisher, R., \& Ilderton, N. A. (2011). Was the Tea Party responsible for the Republican Victory in the 2010 House elections? 2011 Annual Meeting, APSA, Seattle.

Bradbury, L. A., \& Jacobson, G. G. (2013). Does the Tea Party still matter? Tea Party influence in the 2012 election. 2013 Annual 
Meeting, APSA, Chicago.

Burns, J. M. (1978). Leadership. New York: Harper Perennial.

Dye, T. R. (1998). Understanding public policy (9th ed.). Saddle River, New Jersey: Prentice Hall.

Edwards, G. C. III. (2009). The strategic president: Persuasion and opportunity in presidential leadership. Princeton: Princeton University Press.

Edwards, G. C. III. (2012). Overreach: Leadership in the Obama Presidency. Princeton: Princeton University Press.

Edwards, G. C. III. (2013). Persuasion is not power: The nature of presidential leadership. Paper at the Annual Meeting of the American Political Science Association, Chicago, Illinois, August 29-September 1, 2013.

Fisher, P. (2014). The Tea Party gap within the Republican Party. 2014 Annual Meeting of the American Political Science Association, Washington, DC.

Formisano, R. P. (2012). The Tea Party. Baltimore: Johns Hopkins Press.

Lowi, T. J. (1985). The personal president: Power invested, promise unfulfilled. Ithaca: Cornell University Press.

Miroff, B., \& Skowronek, S. (2014). Rethinking presidential studies through historical research: Introduction. Presidential Studies Quarterly, 44(1), 1-5.

Morris, E. (1999). Dutch: A memoir of Ronald Reagan. New York: Random House.

Neustadt, R. E. (1990). Presidential power and the modern presidents: The politics of leadership from Roosevelt to Reagan. New York: the Free Press.

Obama, B. (2006). The audacity of hope: Thoughts on reclaiming the American Dream. New York: The Free Press.

Paul, R., \& Hunter, J. (2011). The Tea Party goes to Washington. New York: Center Street.

Rudalevige, A. (2013). Narrowcasting the Obama Presidency. Perspectives on Politics, 11(4), 1126-1134.

Sabato, L. J. (Ed.) (2013). Barack Obama and the New America: The 2012 election and the changing face of politics. New York: Rowman \& Littlefield Pub., Inc..

Skocpol, T. (2012). Obama and America's political future. Cambridge, Mass: Harvard University Press.

Skocpol, T., \& Williamson, V. (2012). The Tea Party and the remaking of American conservatism. New York: Oxford University Press.

Skowronek, S. (1997). The politics Presidents make: Leadership from John Adams to Bill Clinton. Cambridge, Mass: Belknap Press of Harvard University Press.

Skowronek, S. (2011). Presidential leadership in political time: Reprise and reappraisal (2nd ed.). Lawrence, KA: University Press of Kansas.

Stockman, D. A. (1986). The Triumph of politics: Why the Reagan revolution failed. New York: Harper \& Row.

Thompson, W. A. P. Jr. (2012). Analysis of opposition to F. D. R.'s and Obama's policies to end the great recession. Paper presented at the 2012 Southern Political Science Association, New Orleans, March 27-30, 2012.

Thompson, W. A. P. Jr. (2013). 2012 presidential election: How and why President Barack Obama succeeded in winning the election. Paper presented at the Southwestern Political Science Association, New Orleans, March 27-30.

Thompson, W. A. P. Jr. (2014). Presidents Roosevelt and Obama countered conservative opposition in winning reelection in 1936 and 2012 in determining whether FDR and Obama deserve to be considered transformational in utilizing progressive policies in providing solutions to the Great Depression and Great Recession. Paper presented at the Southwestern Political Science Association, San Antonio, April 17-19, 2014. 